\title{
EVALUASI PROGRAM KELOMPOK KERJA GURU (MGMP) PENDIDIKAN AGAMA ISLAM TINGKAT SMP DI KOTA MASOHI KABUPATEN MALUKU TENGAH
}

\author{
St. Jumaeda \\ PAI FITK IAIN Ambon \\ jumaeda@iainambon.ac.id \\ Nursaid \\ PAI FITK IAIN Ambon
}

\begin{abstract}
This research aims to determine the level of achievement of the activities of the MGMP subjects of Islamic religious education at junior high school level (SMP) in Masohi regency of Maluku Tengah. The study uses evaluative research methods on the MGMP activities of these PAl subjects using goal-oriented evaluation models developed by Ralph Winfred Tyler. Where the focus is on research into the level of goal achievement. Data collection In this study, conducted using observation techniques, interviews, questionnaires, and documentation. Subjects in the study were principals, PAI teachers, and MGMP-PAI administrators of Masohi. Results showed that the result of input evaluation related to MGMP-level capacity of Junior High School includes activity activities MGMP PAI has an average score, $85.78 \%$, performance management MGMP PAI has an average score of $90.04 \%$, facilities and infrastructure MGMP has an average score of $75.25 \%$, KTSP availability in school member MGMP has a score of $92.75 \%$. The implementation of learning has an average score of $88.02 \%$, and the learning results assessment has an average score of $84.17 \%$. Overall evaluation of inputs related to MGMP capacity of PAI at SMP level in Masohi is in good category. While for the output aspect related to the competency of teachers in school member MGMP, has an average value of $90.47 \%$ or the competency of the teacher is in good category.
\end{abstract}

Keywords: Evaluation, MGMP-PAl, Teacher Competence.

\begin{abstract}
Abstrak:Penelitian ini bertujuan untuk mengetahui tingkat ketercapaian tujuan kegiatan MGMP mata Pelajaran Pendidikan Agama Islam pada tingkat Sekolah Menengah Pertama (SMP) di Masohi Kabupaten Maluku Tengah. Penelitian ini menggunakan metode Penelitian evaluatif terhadap kegiatan MGMP mata pelajaran PAI ini menggunakan model evaluasi berorientasi pada tujuan (goal-oriented) yang dikembangkan oleh Ralph Winfred Tyler. Di mana fokusnya adalah penelitian terhadap tingkat ketercapaian tujuan. Pengumpulan data dalam penelitian ini, dilakukan dengan menggunakan teknik observasi, interview, kuesioner, dan dokumentasi. Subyek dalam penelitian ini adalah kepala sekolah, guru PAI, dan pengurus MGMP-PAI kota Masohi. Hasil penelitian menunjukkan bahwa hasil evaluasi input terkait kapasitas MGMP tingkat SMP meliputi keaktifan kegiatan MGMP PAI memiliki skor rata-rata, 85,78\%, Kinerja Pengurus MGMP PAI memiliki skor rata-rata sebesar $90,4 \%$, Sarana dan prasarana MGMP memiliki skor rata-rata sebesar 75,25\%, Ketersediaan KTSP di Sekolah anggota MGMP memiliki skor sebesar 92,75\%. Pelaksanaan pembelajaran memiliki skor rata-rata sebesar $88,02 \%$, dan Penilaian hasil pembelajaran memiliki skor rata-rata sebesar $84,17 \%$. Secara keseluruhan evaluasi input terkait dengan kapasitas MGMP PAI pada tingkat SMP di Masohi berada pada kategori baik. Sementara untuk aspek output terkait dengan Kompetensi guru di Sekolah anggota MGMP, memiliki rata-rata nilai $90,47 \%$ atau kompetensi guru berada pada kategori baik.
\end{abstract}

Kata Kunci: Evaluasi, MGMP PAI, Kompetensi Guru. 


\section{PENDAHULUAN}

Kegiatan pengembangan profesi guru terkait langsung dengan tugas utama guru yaitu membuat perangkat pembelajaran, melaksanakan kegiatan pembelajaran dan menilai serta melakukan evaluasi terhadap proses dan hasil belajar. (Danim, 2017: 27). Penilaian terhadap proses dan hasil pembelajaran pembelajaran tidak terlepas dari perencanaan dan pelaksanaan proses pembelajaran guru, karena itu diperlukan suatu wadah bagi guru untuk meningkatkan kemampuan profesional guru. ( Supardi, 2015:v)

Dalam konteks profesi guru agama, kompetensi guru harus berpijak pada Peraturan Menteri Agama Nomor 16 Tahun 2010 Pasal 16 ayat (1), yaitu kompetensi pedagogik, kepribadian, sosial, profesional, dan kepemimpinan. (PMA, 2010: 10). Dengan ditetapkannya jenis kompetensi guru tersebut, dapat dijadikan dasar dalam menentukan guru yang memiliki kompetensi penuh dengan guru yang kurang memadai kompetensinya. Kompetensi tersebut merupakan satu kesatuan yang utuh dan membentuk konfigurasi yang menggambarkan sosok guru yang profesional. Oleh karena itu, informasi tentang hal ini sangat diperlukan dalam rangka pembinaan dan pengembangan keprofesian guru dan untuk peningkatan kualitas pendidikan nasional.(Syamsu, 2017:2)

Peningkatan kemampuan profesional guru Pendidikan Agama Islam dapat dilakukan dengan sistem pembinaan profesional melalui pembentukan gugus sekolah dan melalui pembinaan profesional di masing-masing sekolah. Pada setiap gugus dibentuk kelompok kegiatan guru, di SMP/MI disebut Kelompok Kerja Guru/MGMP/MGMPS sedangkan di SMP/MTs, dan SMA/ MA/SMK disebut Musyawarah Guru Mata Pelajaran (MGMP/MGMPS). Walaupun gugus sekolah sudah dibentuk dan kegiatan kelompok kerja guru melalui MGMP/MGMPS dan MGMP/MGMPS telah berjalan, namun pelaksanaan kegiatan ini sering kurang memadai sebagai forum untuk 
meningkatkan mutu pembelajaran di sekolah/Madrasah. Adanya Kelompok Kerja Guru (MGMP) yang anggotanya semua guru di dalam gugus yang bersangkutan dimaksudkan sebagai wadah pembinaan profesional bagi para guru dalam upaya meningkatkan kemampuan profesional guru khususnya dalam melaksanakan dan mengelola pembelajaran. ( Aqib, 2009:50)

Rendahnya mutu pendidikan sangat terkait dengan mutu tenaga kependidikan di lapangan. Salah satu tenaga kependidikan itu adalah guru. Karena itu, kemampuan guru perlu dibina dan ditingkatkan, peningkatan kemampuan guru harus dilaksanakan terus menerus. Salah satu strategi dalam melaksanakan upaya peningkatan mutu guru yaitu melalui pendidikan dan pelatihan serta pengembangan Sistem Pembina Profesi (SPP) dalam suatu wadah yang dilengkapi dengan perangkat komponen penunjang lainnya. Wadah tersebut adalah Kelompok Kerja Guru (MGMP).

MGMP merupakan wadah pembinaan guru-guru atau tempat peningkatan profesional guru. Dalam laporan penelitian Bedjo Sujanto, dkk, menyatakan bahwa MGMP dibentuk dalam rangka memberikan dorongan atau motivasi kepada guru agar secara kompetitif mampu mengembangkan diri, yang pada akhirnya diharapkan dapat meningkatkan kualitas kerjanya.(Sujanto, 2000:6)

Eksistensi Musyawarah Guru Mata Pelajaran (MGMP) sebagai organisasi profesi guru menjadi salah satu basis upaya meningkatkan profesionalisme guru. Peningkatan tersebut dapat diperoleh berdasarkan kemampuan memahami dan melaksanakan program MGMP secara optimal dan konsisten, yaitu ruang lingkup dan prinsip kerja MGMP, peran dan kolaborasi MGMP, fungsi MGMP dalam konteks manajemen sekolah, dan materi MGMP. (Hamalik, 2003: 35).

MGMP berfungsi sebagai wadah untuk mengantisipasi berbagai masalah yang ditemui guru dalam melaksanakan kegiatan belajar mengajar di kelas, selain itu juga guru dapat bertukar pikiran, mengangkat masalah 
bersama dalam MGMP memecahkan dan mencari jalan terbaik secara bersama dan dibantu Tutor inti dan guru pemandu mata pelajaran. Aktivitas tukar pengalaman akan dapat menambah pengetahuan dan ketrampilan guru dan akhirnya mempunyai dampak terhadap kinerja guru. Melalui MGMP guru dengan mudah mencari dan menemukan perbaikan-perbaikan dalam proses belajar mengajar.

MGMP sebagai kelompok kerja seluruh guru dalam suatu gugus, pada tahap pelaksanaan dapat dibagi ke dalam kelompok kerja guru yang lebih kecil, yaitu kelompok kerja guru atas dasar jenjang kelas, kelompok kerja guru atas dasar mata pelajaran. Kegiatan tersebut berfungsi: (1) Menyusun program kegiatan MGMP satu tahun dibimbing pengawas, tutor dan guru pemandu; (2) Menampung dan memecahkan masalah yang di hadapi guru dalam KBM melalui pertemuan, diskusi, contoh mengajar, demonstrasi penggunaan dan pembuatan alat peraga. (Dirjen Pendidikan Dasar dan Menengah, 1995:19)

Kehadiran, MGMP bagi guru dapat memberikan dampak positif terhadap kemampuan mengajar guru Pendidikan Agama Islam jika dikelola dan dilaksanakan dengan baik. Namun di lapangan diperoleh bahwa MGMP belum dikelola dan dilaksanakan sebagaimana diharapkan. Hal ini dilihat dari beberapa fenomena antara lain: waktu yang sangat terbatas, materi MGMP dan belum sesuai dengan kebutuhan guru dalam kelas. Selain itu kegiatannya menurut guru-guru belum dilakukan secara teratur, pengelompokan guru berdasarkan kelas belum diatur sedemikian rupa, sehingga pembahasan materi dalam MGMP dirasakan kurang efektif, dan manfaatnya kurang dirasakan oleh guru.

Melalui wadah MGMP inilah guru berkumpul, berdiskusi membicarakan hal yang berkaitan dengan tugas mengajar dan mendidik. Permasalahan yang dihadapi guru Pendidikan Agama Islam di lapangan, selama ini yang namanya MGMP tidak difungsikan secara maksimal, ini 
disebabkan guru-guru kurang paham cara mengelola MGMP yang benar. Kegiatan tersebut hanya dilakukan untuk membuat program dan persiapan mengajar saja. Guru tidak tahu kemana harus bertanya bila dia menghadapi permasalahan tentang materi pelajaran atau bagaimana menggunakan alat peraga atau metode dan model pembelajaran yang cocok digunakan.

Pola MGMP dapat membantu memecahkan permasalahanpermasalahan yang dihadapi guru di lapangan, dengan demikian minat guru untuk datang ke MGMP lebih kuat karena yang mereka cari mereka dapat di MGMP. Dari fenomena yang ditemui di lapangan, mayoritas peserta MGMP hadir dalam setiap kegiatan, meski begitu ada beberapa peserta MGMP yang hadir setelah jam kegiatan MGMP dimulai, peserta MGMP terlihat tidak aktif dan kurang bersemangat dalam kegiatan MGMP, narasumber dalam kegiatan MGMP berasal dari perangkat keanggotaan, dan narasumber menyajikan materi dengan metode ceramah dan diskusi. Namun itu hanyalah gambaran secara umum, bagaimana dengan realitanya di lapangan dan bagaimana pandangan guru selaku subjek dari program MGMP ini. Untuk itulah penulis mencoba mengkaji lebih jauh tentang kegiatan MGMP Pendidikan Agama Islam di Masohi Kabupaten Maluku Tengah.

MGMP merupakan suatu kelompok yang memiliki aktifitas tertentu yang melalui kelompok terjadi proses interaksi. Hal tersebut karena kelompok sebagai kumpulan orang yang mempunyai fungsi komunikatif dan sebagai ikatan dan jembatan untuk mengubah dan membina perilaku orang lain. Dengan demikian, secara komunikasional, kelompok dapat berfungsi sebagai (1) menjalin rasa kebersamaan individu yang memiliki tujuan yang sama, (2) memberikan informasi kepada anggota, (3) memberikan instruksi, (4) mempersuasi anggota, (5) mengintegrasikan sikap, orientasi, dan norma anggota, (5) memberikan peluang pada anggota untuk memperoleh kepuasan. (Nurhattati, 1997:19)

MGMP berfungsi sebagai forum konsultasi antar sesama guru dalam 
peningkatan kemampuan profesional, sedangkan tujuan dari MGMP adalah untuk (1) membina kemampuan akademik serta meningkatkan kompetensi guru, (2) meningkatkan rasa kebersamaan dan tangggung jawab sebagai pendidik untuk menciptakan budaya belajar yang unggul dalam menghasilkan keluaran (lulusan) yang berkualitas, (3) menumbuhkan kegairahan guru dalam mempersiapkan, melaksanakan dan mengevaluasi program Kegiatan Belajar Mengajar (KBM), (4) mengurangi kesenjangan kompetensi antar guru sehingga dapat menunjang usaha peningkatan dan pemerataan mutu, (5) mengidentifikasi permasalahan yang dihadapi guru dalam melaksanakan tugas sehari-hari dan bertukar pikiran untuk mencari alternatif penyelesaiannya, (6) Membantu guru dalam upaya memenuhi kebutuhannya yang berkaitan tugas profesionalnya sebagai pendidik, (7) membantu guru memperoleh berbagai informasi kependidikan, baik yang menyangkut kebijakan pendidikan maupun teknis pembelajaran, (8) membantu guru untuk bekerjasama dalam meningkatkan mutu kegiatan pembelajaran, baik yang terstruktur maupun yang tidak terstruktur, (9) memperluas wawasan dan saling tukar menukar informasi dan pengalaman antar guru agar tetap mengikuti perkembangan yang terjadi terkait dengan pendidikan dan pembelajaran, dan (10) meningkatkan semangat untuk memacu diri dan meraih prestasi terbaik dalam pendidikan dan pembelajaran. (Dirjen Pendidikan Islam,2007:1)

Evaluasi terhadap kegiatan MGMP pada dasarnya dilaksanakan oleh anggota, pada setiap tingkat, baik di tingkat gugus, kecamatan, kabupaten/kota maupun propinsi dan nasional. Adapun pemantauan dapat dilakukan oleh komite Sekolah/Madrasah, pengawas, Kantor Departemen Agama, Kantor Wilayah Departemen Agama dan Direktorat Pendidikan Madrasah. Pemantauan dan evaluasi ini dimaksudkan untuk meningkatkan peran, fungsi serta kinerja MGMP dalam peningkatan kemampuan dan kompetensi guru PAI Pada tingkat SMP. Pelaksanaan program MGMP PAI 
yaitu membahas berbagai kesulitan guru dalam mengajar, memecahkan masalah yang dihadapinya, dan melatih guru PAI baik dalam penggunaan teknologi, penguasaan materi pelajaran maupun dalam membagi pengalaman mengajar.(Pratama dkk, 2018:27)

Sasaran evaluasi dan pemantauan kegiatan MGMP meliputi: (1) Perencanaan, terdiri dari rencana kegiatan dalam kurun waktu tertentu (2) proses, terdiri dari jadwal pertemuan, kehadiran dan keaktifan anggota, isi kegiatan, narasumber dan fasilitator, pendanaan, kendala atau masalah yang dihadapi dan alternatif solusi (3) Keluaran, terdiri dari out put fisik, Hasil karya, dan Dampak dalam bentuk kemampuan dan ketrampilan guru. ( Dirjen Kelembagaan Islam, 2002: 12) Sebagai bagian dari proses pemantauan dan evaluasi, dilakukan pula supervisi, pendampingan dan konsultasi. Dalam rangka kordinasi dan kemitraan, rencana dan pelaksanaan kegiatan serta evaluasi hasil evaluasinya diberitahukan dan disampaikan secara berkala kepada Kantor Departemen Agama Kabupaten/Kota, Kantor Wilayah Departemen Provinsi, dan Departemen Agama Pusat. Hal ini dimaksudkan untuk memudahkan perumusan kebijakan dan penyusunan program terkait kemitraan, pemberdayaan, atau pembinaan MGMP-PAI oleh Departemen Agama.

\section{METODE}

Penelitian Evaluasi program kegiatan Kelompok Kerja Guru PAI menggunakan metode penelitian evaluasi dengan model evaluasi berorientasi pada tujuan (goal-oriented) yang dikembangkan oleh Ralph Winfred Tyler. Di mana fokusnya adalah penelitian terhadap tingkat ketercapaian tujuan. (Arikunto, dan Abdul Jabar 2012:49). Penelitian ini dilaksanakan pada 16 SMP yang memiliki guru PAl anggota MGMP di Masohi kabupaten Maluku Tengah. 
Evaluasi program kegiatan MGMP mata Pelajaran PAI di Masohi menggunakan empat jenis instrumen penelitian yaitu dokumen, wawancara, observasi, kuesioner. Dalam melakukan evaluasi ini terdapat dalam dua aspek evaluasi input dan output. Instrumen input terdiri atas (a) studi dokumen yakni penelusuran dan analisis dokumen keaktifan MGMP, inventory checklist sarana dan prasarana MGMP dan ketersediaan KTSP di Sekolah anggota MGMP (b) pedoman wawancara digunakan untuk menanyakan hal-hal yang berhubungan dengan keaktifan kegiatan MGMP, kinerja pengurus MGMP, sarana dan prasarana MGMP, ketersediaan KTSP di Sekolah anggota MGMP, (c) observasi untuk mengamati pelaksanaan dan penilaian hasil pembelajaran yang dilakukan guru di kelas, dan (d) kuesioner untuk mengungkap sejauhmana kinerja pengurus MGMP mata Pelajaran PAI di Masohi. Instrumen output terdiri atas kuesioner untuk mengungkap sejauhmana Kompetensi guru anggota MGMP mata Pelajaran PAI di Masohi.

\section{HASIL}

Temuan di lapangan, menunjukkan bahwa keaktifan pengurus Musyawarah Guru Mata Pelajaran PAI pada tingkat SMP berkomitmen tetap mengaktifkan dan memberdayakan MGMP PAI dilatarbelakangi faktor internal yaitu masih ditemukannya guru PAI yang memiliki kompetensi kurang memadai, dalam perencanaan pembelajaran, pelaksanaan pembelajaran dan melakukan evaluasi pembelajaran. (Wawancara, 8 Juli 2019).

Adapun hasil evaluasi dari kapasitas MGMP mata pelajaran PAI di Masohi sebagaimana berikut.

\section{Evaluasi Input}

\section{a. Keaktifan MGMP Mata Pelajaran PAI di Masohi}

Penilaian terhadap keaktifan MGMP mata pelajaran PAI di Masohi dianalisis berdasarkan dokumen daftar hadir pengurus, dan kehadiran peserta kegiatan dengan presentase $85,78 \%$. Ini menunjukkan bahwa MGMP mata pelajaran 
PAl di Masohi aktif dan secara rutin dilaksanakan dan dihadiri peserta, pengurus maupun instruktur/fasilitator.

\section{b. Kinerja Pengurus MGMP mata pelajaran PAI di Masohi}

Kinerja pengurus MGMP mata pelajaran PAI di Masohi memiliki nilai rata-rata sebesar 90,4\%. Dengan demikian hasil evaluasi sesuai dengan kriteria keberhasilan yang dibuat, maka menunjukkan bahwa kinerja pengurus MGMP mata pelajaran PAI di Masohi masuk pada ketegori baik.

\section{c. Sarana dan prasarana MGMP mata pelajaran PAI di Masohi}

Sarana dan prasarana yang menunjang program kegiatan MGMP mata pelajaran PAI di Masohi sebagian besar menunjukkan bahwa sarana dan prasarana yang menunjang kegiatan MGMP mata pelajaran PAI di Masohi cukup, hasil yang diperoleh yakni rata-rata nilai sebesar $75,25 \%$, dengan demikian sarana dan prasarana MGMP mata pelajaran PAI di Masohi cukup memadai, sebab MGMP belum memiliki ruang pertemuan tersendiri sehingga kegiatan MGMP biasa dilakukan secara bergilir pada sekolahsekolah gugus anggota MGMP.

\section{d. Ketersediaan KTSP di SMP Anggota MGMP di Masohi}

hasil penilaian terhadap ketersediaan KTSP di SMP anggota MGMP di Masohi sebanyak 5 SMP terdiri atas 3 sekolah negeri dan 2 sekolah swasta yaitu: SMP Neg. 1 Masohi, SMP Neg. 2 Masohi, SMP Neg. 3 Masohi, SMP Muhammadiyah Masohi, dan SMP Islam Al-Bina Masohi diketahui bahwa visi dan misi di SMP anggota MGMP di Masohi memiliki nilai rata-rata $92.75 \%$ yang berarti ada dan lengkap serta sesuai, hal ini menunjukkan bahwa di SMP anggota MGMP telah baik dalam merumuskan visi dan misi Sekolah berdasarkan masukan dari berbagai warga Sekolah dan dijadikan cita-cita bersama warga Sekolah dan segenap pihak yang berkepentingan pada masa yang akan datang dan dinilai cukup baik. Untuk tujuan Sekolah, rencana 
kerja Sekolah dan kalender akademik dan perangkat pembelajaran di SMP anggota MGMP memiliki nilai rata-rata $100 \%$ yang berarti ada dan lengkap. Ini menunjukkan bahwa tujuan Sekolah, rencana kerja sekolah dan kalender akademik dan perangkat pembelajaran di SMP anggota MGMP telah lengkap dan sesuai.

\section{e. Pelaksanaan Pembelajaran di Sekolah anggota MGMP}

Pelaksanaan pembelajaran di sekolah anggota MGMP tingkat SMP mata pelajaran PAI di Masohi untuk aspek kegiatan awal yang dilakukan oleh guru di kelas memiliki skor sebesar $88,75 \%$. Hal ini berarti untuk kegiatan awal dinilai baik sehingga dengan kegiatan awal tersebut siswa dianggap telah siap mengikuti pembelajaran. untuk aspek kegiatan inti yang dilakukan oleh guru di kelas pada MGMP SMP di Masohi memiliki skor sebesar $86,3 \%$. Hal ini menunjukkan kegiatan inti pelaksanaan pembelajaran yang dilakukan oleh guru dinilai baik. Terakhir untuk aspek kegiatan akhir yang $89 \%$. Nilai ini menunjukkan pelaksanaan kegiatan akhir yang dilakukan oleh guru dinilai baik.

\section{f. Pelaksanaan Penilaian hasil pembelajaran di sekolah anggota MGMP}

Penilaian hasil pembelajaran untuk anggota MGMP tingkat SMP memiliki skor sebesar $84,17 \%$. Hal ini menunjukkan bahwa untuk penilaian hasil belajar di SMP mata pelajaran PAI anggota MGMP di Masohi dinilai baik. Secara keseluruhan penilaian hasil belajar di sekolah anggota MGMP mata pelajaran PAI di Masohi dinilai baik. Dengan demikian hasil evaluasi sesuai dengan kriteria keberhasilan atau standar objek yang dibuat, maka menunjukkan bahwa penilaian hasil pembelajaran di Sekolah anggota MGMP mata pelajaran PAI di Masohi berlangsung pada ketegori baik.

\section{Aspek evaluasi output}

a. Kompetensi Paedagogik 
Penilaian kompetensi Paedagogik, dapatlah diperoleh skor rata sebesar $90 \%$. Ini menunjukkan bahwa pemahaman wawasan, pemahaman terhadap peserta didik, perencanaan dan pelaksanaan pembelajaran, evaluasi hasil belajar serta pengembangan peserta didik.

\section{b. Kompetensi profesional}

penilaian kompetensi profesional, dapatlah diperoleh presentase sebesar $88,23 \%$. Ini berarti bahwa konsep struktur dan metode keilmuan, materi ajar, hubungan konsep antar keilmuan dalam kehidupan sehari-hari.

\section{c. Kompetensi kepribadian}

penilaian kompetensi kepribadian, dapatlah diperoleh presentase sebesar 92,36\%. Hal ini menunjukkan bahwa guru PAI menjadi teladan bagi peserta didik dan masyarakat dalam mengembangkan diri secara berkelanjutan, dewasa, arif, dan bijaksana, serta berwibawa.

\section{d. Kompetensi sosial}

penilaian kompetensi sosial, dapatlah diperoleh presentase sebesar $91,3 \%$. Hal ini menunjukkan bahwa guru PAI mampu berkomunikasi lisan dan tulisan, bergaul secara efektif dengan guru, siswa dan masyarakat sekitar.

\section{PEMBAHASAN}

\section{Aspek evaluasi Input}

Program kegiatan MGMP PAI pada di Masohi yang dilaksanakan berdasarkan analisis dokumen menunjukkan bahwa MGMP PAI di Masohi aktif melakukan kegiatan sesuai dengan program kegiatan yang telah direncanakan. Pengurus MGMP PAl tingkat SMP di Masohi mempunyai motivasi untuk mengelola kegiatan MGMP, mereka berusaha memenuhi kebutuhan guru yang berkaitan dengan kegiatan MGMP dan bersama-sama teman lain mengatur jadwal kegiatan. Dalam menghadapi permasalahan 
kegiatan, pengurus selalu mendiskusikan terlebih dahulu dengan temanteman lain untuk menyelesaikan permasalahan tersebut, melakukan evaluasi kegiatan dan pemantauan kegiatan, berkoordinasi dengan pengawas Sekolah serta dari pihak Kantor Kementerian Agama Kabupaten Maluku Tengah. Demikian pula Sarana dan prasarana penunjang program kegiatan MGMP PAI tingkat SMP di Masohi cukup memadai.

Ketersediaan KTSP di SMP anggota MGMP di Masohi menunjukkan bahwa visi dan misi sekolah lengkap dan sesuai, hal ini berarti, SMP anggota MGMP di Masohi telah merumuskan visi dan misi Sekolah berdasarkan masukan dari berbagai warga sekolah dan dijadikan cita-cita bersama warga sekolah dan segenap pihak yang berkepentingan pada masa yang akan datang. Untuk Rencana kerja sekolah, tujuan sekolah dan kalender akademik dan seluruh perangkat pembelajaran juga lengkap dan sesuai..

Pelaksanaan pembelajaran di sekolah anggota MGMP PAl tingkat SMP di Masohi untuk aspek kegiatan awal yang dilakukan oleh guru PAI dinilai baik. Hal ini berarti siswa telah siap mengikuti pembelajaran. Untuk aspek kegiatan inti yang dilakukan oleh guru PAI anggota MGMP di Masohi juga dinilai baik. Demikian pula untuk aspek kegiatan akhir yang dilakukan oleh guru PAI anggota MGMP di Masohi juga dinilai baik. Demikian pula penilaian hasil pelaksanaan pembelajaran di sekolah anggota MGMP pada mata pelajaran PAI tingkat SMP di Masohi juga telah tercapai.

\section{Aspek Evaluasi Output}

Kompetensi Pedagogik guru PAI anggota MGMP tingkat SMP sepenuhnya telah sungguh-sungguh dalam mempersiapkan pembelajaran, memiliki keteraturan dan ketertiban penyelenggaraan pembelajaran, kemampuan menghidupkan suasana kelas, kedisiplinan dan kepatuhan terhadap aturan akademik, kemampuan melaksanakan penilaian prestasi 
siswa, objektivitas dalam penilaian terhadap siswa, kemampuan membimbing siswa, serta berpersepsi positif terhadap kemampuan siswa.

Kompetensi profesional guru PAI anggota MGMP tingkat SMP ditunjukkan dengan penguasaan bidang keahlian yang menjadi tugas pokok guru, kemampuan menunjukkan keterkaitan bidang studi yang diajarkan dengan konteks kehidupan, kesediaan melakukan refleksi dan diskusi permasalahan pembelajaran yang dihadapi dengan teman guru, melibatkan siswa dalam pengembangan pembelajaran. Demikian pula dengan keterlibatan guru dalam kegiatan ilmiah organisasi profesi guru dengan mengembangkan diri untuk memperoleh pembelajaran yang bermutu

Kompetensi kepribadian guru PAI anggota MGMP, ditunjukkan dengan menjaga kewibawaan sebagai pribadi guru, kearifan dalam mengambil keputusan, menjadi contoh dalam bersikap dan berprilaku, kemampuan mengendalikan diri dalam berbagai situasi dan kondisi serta adil dalam memperlakukan sejawat dan siswa.

Kompetensi sosial guru PAI anggota MGMP ditunjukkan dengan kemampuan guru dalam menyampaikan pendapat, kemampuan menerima kritik, saran dan pendapat guru, mudah bergaul sesama guru, siswa dan masyarakat sekitar serta mempunyai sikap toleransi terhadap keberagaman di masyarakat.

\section{KESIMPULAN}

Program kegiatan MGMP PAI tingkat SMP di Masohi dilakukan secara rutin di sekolah gugus yang memerlukannya, kegiatan ini dirasakan penting oleh guru, sehingga guru mengikuti kegiatan MGMP PAI secara aktif. Kinerja Pengurus MGMP baik dalam kedisiplinan dalam melaksanakan tugas, tanggung jawab penyelesaian tugas, kesungguhan dalam memecahkan masalah yang dihadapi serta meningkatkan usaha dalam melaksanakan tugas dan moral kerja. Sarana dan prasarana MGMP PAI di Masohi cukup 
memadai. Ketersediaan KTSP di sekolah anggota MGMP PAl tingkat SMP di Masohi lengkap dan sesuai. Sementara pelaksanaan dan penilaian pembelajaran di kelas yang dilakukan guru menjadikan siswa nyaman dan sungguh-sungguh dalam menerima materi selama pelaksanaan pembelajaran di kelas. Demikian pula dengan kompetensi yang dimiliki guru PAl sudah baik namun, perlu ditingkatkan untuk lebih meningkatkan hasil belajar siswa sehingga kinerja guru dapat meningkatkan output yang lebih baik.

\section{DAFTAR PUSTAKA}

[1] Aqib, Zainal. (2009). Belajar dan Pembelajaran di SMP. Bandung: Yrama Widya.

[2] Arikunto, Suharsimi dan Abdul Jabar.(2012). Evaluasi Program Pendidikan, Jakarta: Bumi Aksara.

[3] Danim, Sudarman. Profesionalisasi dan Etika Profesi Guru, Bandung: Alfa Beta, 2017.

[4] Hamalik. (2003). Proses Belajar Mengajar. Jakarta: Bumi Aksara.

[5] Nurhattati. (1997). Efektifitas MGMP dalam upaya Peningkatan Kualitas Mengajar Guru di Kota Administratif Bekasi Jawa Barat. Hasil Penelitian.

[6] Pratama, Satria, Yusrizal dan Niswanto.(2018). Manajemen Musyawarah Guru Mata Pelajaran Pendidikan Agama Islam dalam Peningkatan Profesional Guru pada Forum MGMP SMK I Kabupaten Aceh Jaya, Jurnal Magister Administrasi Pendidikan Pascasarjana Universitas Syiah Kuala, Volume 6. No.1,Februari: 24-29. 
[7] Syamsu. (2017). Peningkatan Kompetensi Guru Pendidikan Agama Islam Berbasis Musyawarah Guru Mata Pelajaran pada Sekolah Menengah Pertama di Kota Palopo Propinsi Sulawesi Selatan Holistic Journal for Islamic Sosial Sciences, Volume.2, Nomor 2:1-9.

[8 Supardi. (2015). Penilaian Autentik Pembelajaran Afektif, Kognitif dan Psikomotorik, Jakarta: Raja Grafindo Persada.

[9) Sujanto, Bedjo. (2009). Cara Efektif Menuju Sertifikasi Guru, Jakarta: Raih Asa Sukses.

[10] Direktorat Jenderal Pendidikan Islam, Direktur Pendidikan Madrasah. (2007). Surat Edaran Panduan Kelompok Kerja Guru RA dan MI, Jakarta: Departemen Agama.

[11] Direktorat Jenderal Pendidikan Dasar dan Menengah. (1995). Pedoman Pengelolaan Gugus Sekolah,Jakarat: Departemen Pendidikan dan Kebudayaan.

[12] Direktorat Jenderal Pendidikan Dasar dan Menengah. (1995). Pedoman Pengelolaan Gugus Sekolah, Jakarat: Departemen Pendidikan dan Kebudayaan. 